\title{
EFFECT OF FEEDING DIFFERENT LEVELS OF CORN GLUTEN FEED ON DIGESTION COEFFICIENTS, FEED INTAKE, SOME BLOOD AND RUMEN PARAMETERS IN FRIESIAN DAIRY COWS RATIONS
}

\author{
Eman H.M. Maklad'; M.Y. El-Ayek', A.M. Abd El-Khabir², H.M. Ead', M. E. Sayed- \\ Ahmed $^{2}$ and K. M. I. Sharaf ${ }^{2}$. \\ ${ }^{1}$ Animal Production Department, Faculty of Agriculture, Mansoura University, Egypt. \\ ${ }^{2}$ Animal Production Research Institute, Agriculture Research Center, Ministry of Agriculture, Dokki, \\ Giza, Egypt.
}

(Received 28/6 /2018, accepted 7/8/2018)

SUMMARY

$\mathrm{T}$ welve lactating Friesian cows with the average body weight of $435-570 \mathrm{~kg}$ were used in this study All animals in this study were in the $2^{\text {nd }}$ to $4^{\text {th }}$ lactation season were randomly distributed into four similar groups (three cows for each group). All groups were individually fed according to NRC (2001) recommendations. The four experimental rations were formulated as follows: control: 52\% concentrate feed mixture (CFM) (40\% corn grain, $30 \%$ wheat bran, $23 \%$ undecorticated cottonseed meal, $5 \%$ molasses, $0.5 \%$ salt and $1.5 \%$ limestone) $+20 \%$ corn silage (CS) $+28 \%$ rice straw (RS), experimental ration 1 (Exp.1): 52\% CFM (35\% corn grain, 30\% wheat bran, $10 \%$ corn gluten feed (CG), $18 \%$ undecorticated cottonseed meal, $5 \%$ molasses, $0.5 \%$ salt and $1.5 \%$ limestone) $+20 \% \mathrm{CS}+28 \% \mathrm{RS}$, experimental ration 2 (Exp.2): 52\% CFM ( $32.5 \%$ corn grain, $30 \%$ wheat bran, $15 \%$ CG, $15.5 \%$ undecorticated cottonseed meal, $5 \%$ molass, $0.5 \%$ salt and $1.5 \%$ limestone) $+20 \% \mathrm{CS}+28 \% \mathrm{RS}$ and experimental ration 3 (Exp.3): $52 \%$ CFM (30\% corn grain, $30 \%$ wheat bran, $20 \%$ CG, $13 \%$ undecorticated cottonseed meal, $5 \%$ molasses, $0.5 \%$ salt and $1.5 \%$ limestone) $+20 \%$ CS $+28 \%$ RS. Four digestibility trials were conducted to determine nutrients digestibility coefficients and nutritive values of the experimental rations. Each digestibility trial consisted of 15 days preliminary period followed by 7 days collected period. Results showed that the dry matter intakes (\% body weight) were higher with feeding on Exp.1 or Exp.2 (3.38 and 3.51, respectively) than feeding on control or Exp.3 (3.25 and 3.26, respectively). The apparent digestibility of CP was significantly $(\mathrm{P}<0.05)$ higher with feeding on control (74.60\%) than feeding on Exp.1, Exp.2, and Exp.3 (67.88, 62.12 and 64.57\% respectively). The TDN\% values were $72.74,70.18,66.45$ and $68.8 \%$ with feeding on control; Exp.1, Exp.2 and Exp.3 respectively, and the same trends were also with $\mathrm{ME}(\mathrm{Mcal} / \mathrm{kg}), \mathrm{ME}(\mathrm{Mj} / \mathrm{kg})$ and $\mathrm{NE}_{\mathrm{L}}(\mathrm{Mcal} / \mathrm{kg})$. Total tract digestibility (\%) of starch was lower for the low starch diets, but ruminal digestion (\%) of starch was not affected by starch concentration. The $\mathrm{pH}$ values were ranged from 6.16 to 7.59 with different treatments and at all measuring times. The mean value was higher $(\mathrm{P}<0.05)$ with feeding on control $(6.97)$ and lower with feeding on Exp.1 (6.51), while there were no significant differences when feeding on Exp.2 (6.73) and Exp.3 (6.73) or among Exp.1 and Exp.2 or Exp.3. The mean values showed that the TVFA's concentration was significantly $(\mathrm{P}<0.05)$ higher in control group $(4.43 \mathrm{ml}$ eq. $/ 100 \mathrm{ml} \mathrm{RL})$ than feeding on Exp.1 or Exp.2 or Exp.3 (4.08, 4.01 and $4.18 \mathrm{ml}$ eq. $/ 100 \mathrm{ml} \mathrm{RL}$, respectively), but there was no significant effect among Exp.1, Exp.2 and Exp.3. Ruminal $\mathrm{NH}_{3}-\mathrm{N}$ _concentration was higher $(\mathrm{P}<0.05)$ with feeding on the control or Exp.1 (10.50 and $10.25 \mathrm{mg} / 100 \mathrm{ml}$, respectively) than feeding on Exp.2 (8.42), but there was no significant effect with feeding on Exp.3 $(9.58 \mathrm{mg} / 100 \mathrm{ml})$ or control or Exp.1 or Exp.2. The effective neutral detergent fiber (eNDF) values ranged from 25.58 to $36.63 \%$, the eNDF was higher $(\mathrm{P}<0.05)$ with feeding on control $(36.63 \%)$ than feeding on Exp.1 or Exp. 2 or Exp.3 $(25.58,30.92$ and $30.78 \%$ respectively). The mean value of fibrolytic bacteria was higher $(\mathrm{P}<0.05)$ with feeding on Exp.2 $\left(14.7 \times 10^{5}\right.$ $\mathrm{CFU} / \mathrm{ml}$ ) than feeding on control or Exp.1 or Exp.3 (7.75, 8.12 and $9.65 \times 10^{5} \mathrm{CFU} / \mathrm{ml}$, respectively). On the other hand, the amylolytic bacteria count was ranged from 1.93 to $8.47 \times 10^{5} \mathrm{CFU} / \mathrm{ml}$ with different treatments. The mean value was the highest $(\mathrm{P}<0.05)$ with feeding on the control $\left(6.25 \times 10^{5} \mathrm{CFU} / \mathrm{ml}\right)$ than feeding on Exp.1 or Exp.2 or Exp.3 (3.93, 2.89 and $4.11 \times 10^{5}$ CFU/ ml respectively). The insulin concentration was higher $(\mathrm{P}<0.05)$ with feeding on Exp.3 $(0.25 \mathrm{ng} / \mathrm{ml})$ than feeding on control or Exp.1 or Exp. 2 which were have similar concentration $(0.23 \mathrm{ng} / \mathrm{ml})$. The triglycerides concentrations were ranged from 106.06 to $343.73 \mathrm{mg} / 100 \mathrm{ml}$ with different treatments at all times, the mean values were higher $(\mathrm{P}<0.05)$ with feeding on control and Exp.1 $(246.44$ and $231.39 \mathrm{mg} / 100 \mathrm{ml}$, respectively) than feeding on Exp.2 and Exp.3 (196.21 and $209.13 \mathrm{mg} / 100 \mathrm{ml}$, respectively). The total protein concentrations were ranged from 4.19 to $8.01 \mathrm{~g} / 100 \mathrm{ml}$ with feeding on the experimental rations at all times. The urea concentrations 


\section{Maklad et al.}

were increased with Exp. 1 or Exp. 2 or Exp. 3 than feeding on control at all times. The mean values were higher $(\mathrm{P}<0.05)$ with feeding on Exp.2 or Exp.3 (21.68 and $23.24 \mathrm{~g} / 100 \mathrm{ml}$, respectively) than feeding on control or Exp.1 (16.6 and $18.67 \mathrm{~g} / 100 \mathrm{ml}$ respectively). Corn grain and undecorticated cottonseed meal can be replaced by $15 \%$ corn gluten feed are often considered providing the proper amounts of ruminally fermentable carbohydrates.

Keywords: lactating Friesian cows, corn silage, corn gluten feed, some rumen liquor parameters, fibrolytic bacteria, amylolytic bacteria and some blood parameters.

\section{INTRODUCTION}

There is a deficiency in animal feeds (27\% of calculated requirements) in the northern countries of Africa (Egypt, Algeria, Libya, Morocco and Tunisia). Over the whole year, Usage of the available feed quantities is not at a constant rate. During the winter (rainfall) season, the more nutritious $65 \%$ of available feeds are consumed. While in summer season, animals suffer from severe feed insufficiency due to lack of minerals, nitrogen, vitamin A precursors and soluble carbohydrates at the same time. The northern countries of Africa have considerable amounts of crop residues and agro-industrial by-products which are underutilized. Also, in milk production a diet based on chopped and supplemented by-products resulted in a similar level of milk yield as that obtained on a 1:1 concentrate to green roughage diet (on DM basis), (Kossila, 1981). Removal of starch content of new material is done in most cases. After concentrating the remaining material, the raw product from which they originate is lower in protein, fiber and fat. Despite removing the rapidly-digested starch from the feed, fiber in the form of cellulose remains and is highly digestible by ruminants such as cattle and sheep. Consequently, the energy (TDN) content of these feeds is not very different from the TDN of the whole grain from which these byproducts originate (Wahlberg, 2009). Corn by-products continue to be economical sources of nutrients. Maintaining energy levels and decreasing feed costs can be achieved by using wheat midds, corn gluten feed and soy hulls. Dairy managers and nutritionists must monitor corn by-products as ethanol producers continue to market corn nutrients in by products (Hutjens, 2010), to capture value-added feed markets. Simply, acetic acid is produced by fermentation of fiber (cellulose and hemicellulose), then acetic acid is used for energy by the cow and as a primary precursor of fat in milk. In contrast, propionic acid is produced from digestion of sugars and starches, and then in the liver of the cow propionic acid is changed into glucose and used for energy (Grant, 1997). Corn gluten feed is a by-product of corn syrup manufacturing. This feed has protein that is mostly degradable in the rumen and is not considered a source of rumen resistant protein, while energy is similar to some grains. Corn gluten feed is often an economical feed to use in rations. The precedent part of the present study was to evaluate the replacement of amounts of corn grain and cottonseed meal in the concentrate feed mixture in lactating cows rations by $15 \%$ corn gluten feed are often considered for enhancing production of milk, persistency and economic efficiency (Maklad Eman et al., 2017).

The objective of this study was to evaluate the effect of partially substituting of corn and undecorticated cottonseed meal by corn gluten feed on feed intake, nutrients digestibility, some rumen liquor parameters, fibrolytic bacteria, amylolytic bacteria and some blood parameters of lactating Friesian cows.

\section{MATERIALS AND METHODS}

The present study was conducted at El-Karada Animal Production Research Station, Animal Production Research Institute, Agricultural Research Centre, Ministry of Agriculture. In this study, the weights of the twelve cows were ranging from $435-570 \mathrm{~kg}$. The animals in this study were in the $2^{\text {nd }}$ to $4^{\text {th }}$ lactation season. According to NRC (2001) recommendations all groups were fed individually. The four experimental rations were formulated as follows: control: 52\% concentrate feed mixture (CFM) (40\% corn grain, $30 \%$ wheat bran, $23 \%$ undecorticated cottonseed meal, $5 \%$ molasses, $0.5 \%$ salt and $1.5 \%$ limestone) $+20 \%$ corn silage $(\mathrm{CS})+28 \%$ rice straw (RS), experimental ration 1 (Exp.1): $52 \%$ CFM (35\% corn grain, 30\% wheat bran, 10\% corn gluten feed (CG), 18\% undecorticated cottonseed meal, $5 \%$ molasses, $0.5 \%$ salt and $1.5 \%$ limestone) $+20 \% \mathrm{CS}+28 \% \mathrm{RS}$, experimental ration 2 (Exp.2): 
$52 \%$ CFM ( $32.5 \%$ corn grain, $30 \%$ wheat bran, $15 \%$ CG, $15.5 \%$ undecorticated cottonseed meal, $5 \%$ molass, $0.5 \%$ salt and $1.5 \%$ limestone) $+20 \% \mathrm{CS}+28 \% \mathrm{RS}$ and experimental ration 3 (Exp.3): $52 \%$ CFM (30\% corn grain, 30\% wheat bran, $20 \%$ CG, $13 \%$ undecorticated cottonseed meal, $5 \%$ molasses, $0.5 \%$ salt and $1.5 \%$ limestone) $+20 \% \mathrm{CS}+28 \% \mathrm{RS}$.

Four digestibility trials were conducted using three cows from each group to determine nutrients digestibility coefficients and nutritive values of the experimental rations. Each digestibility trial consisted of 15 days preliminary period followed by 7 days collected period. During the digestion trials, cows were fed their allowances according to the experimental assignment of each group. Acid insoluble ash (AIA) was used as a natural marker (Van keulen and Young, 1977). Nutrients digestibility was calculated from the equations stated by Schneider and Flatt (1975). Samples of concentrate mixture, corn silage and rice straw were taken at the beginning, middle and at the end of each trial. At the end of the collection period composite samples were dried in a forced air oven at $65^{\circ} \mathrm{C}$ for 48 hours, then ground and kept for chemical analysis. Faces samples were taken from the rectum of each cow twice daily with 12 hours interval during the collection period of each trial and dried in a forced air oven at $65^{\circ} \mathrm{C}$ for 48 hours. Dried samples were composted for each cow and representative samples were taken, ground and kept for chemical analysis. Chemical analysis of samples of concentrate mixture, corn silage, and rice straw were carried out to determine dry matter (DM), crude protein (CP), crude fiber (CF), ether extract (EE), ash and fiber fractions (NDF,ADF ADL, Hemi. and Cell.) according to the methods of AOAC (1990).

At the end of the collection period ruminal fluid samples were taken using stomach tube before feeding and at 2, 4 and $8 \mathrm{hrs}$ post-feeding from three animals of each treatment. The collected rumen fluid samples were filtered through three layers of gauze without squeezing for the determination of $\mathrm{pH}$, ammonia-N and total volatile fatty acids (TVFA s). Ruminal $\mathrm{pH}$ was estimated by $\mathrm{pH}$ meter (Orion Research, model 201 digital $\mathrm{pH}$ meter). Ruminal ammonia-N was determined according to Conway (1957). The TVFA's were determined by the steam distillation method as described by Warner (1964). Fibrolytic bacteria (included Fibrobacter succinogenes) counting medium, the Hungate anaerobic culture method as described by Varel and Jung (1986) was used, the composition of the cellulose and xylan agar plate medium per $100 \mathrm{ml}$. Amylolytic bacteria (included Streptococcus bovis) counting medium, Azide dextrose agar was used for counting S. bovis by Abshire (1977).

Blood samples were taken after the end of the collection period from the jugular vein of dairy cows before feeding and at 2, 4 and $8 \mathrm{hrs}$ post- feeding from three animals of each treatment. Blood samples were separated by centrifugation at 4000 r.p.m for 10 minutes. The serum samples were frozen at $-20^{\circ} \mathrm{C}$ until analysis for Leptin, Insulin, FFA, Glucose, Cholesterol, Triglycerides, Total protein, urea and NEFA (None esterified fatty acids). Different items of the blood picture tested in this experiment were carried out according to the corresponding references illustrated in the following illustration using commercial Kits,

References used for the blood profile analyses were as follows:

\begin{tabular}{ll}
\hline Criteria & References \\
\hline Leptin & Ahima and Flier (2000) \\
Insulin & Cohen et al. (1996) \\
FFA & Zollner and Kirsch (1962) \\
Glucose & Trinder (1969) \\
Cholesterol & Allain et al. (1974) \\
Triglycerides & Fossati and Prencipe (1982) \\
Total Protein & Gornall et al. (1949) \\
Urea & Faweett and Scott (1960) \\
NEFA (Non esterified fatty acids) & Cunningham (1992) \\
\hline
\end{tabular}

Data were statistically analyzed by variance test method according to Snedecor and Cochran (1982) while the differences among means were tested using Duncan's Multiple Range Test (Duncan, 1955).

\section{RESULTS AND DISCUSSION}

Chemical composition of the ingredients and experimental rations were as shown in Table (1). The CP\% was higher for CG 10\%, CG 15\% and CG20\% of CFM and lower in CF, ADF and ADL\% 
compared with $\mathrm{CG} 0 \%$ of CFM. However, the CFM with or without CG were contained similar values of NFE, Ash, NDF, hemicellulose and NFC \%. The chemical compositions of the experimental rations were contained similar of all nutrients. The $\mathrm{CP} \%$ values ranged from 10.32 to 11.85 , $\mathrm{ADF} \%$ values were from 34.56 to 35.41 and NFC\% values were ranged from 26.00 to 26.35 . The average daily dry matter intake of each experimental ration was shown in Table (2). The dry matter intake (\% body weight) was higher with feeding on Exp.1 or Exp.2 than feeding on control or Exp.3. The NRC (1989) recommended that diets for lactations dairy cows should contain minimum of $25 \%$ to $28 \%$ of the total DM as NDF, and it is suggested that $75 \%$ of that NDF should be from a forage source. For providing highly digestible neutral detergent fiber (NDF) and non-fiber carbohydrates, utilization of more by-product feeds and high-quality forage was suggested as a strategy for lactating cow diets with high corn prices (Shaver, 2008).

As shown in Table (3), the apparent digestibility of $\mathrm{CP}$ was significantly $(\mathrm{P}<0.05)$ higher with feeding on control than feeding on Exp.1, Exp.2, and Exp.3, but there was no significant effect among the experimental diets Exp.1, Exp.2 and Exp.3. The NFC digestibility was higher with feeding on control than feeding on Exp.2, but without significant effects with feeding on Exp.1 or with Exp.3, also there was no significant effect among Exp.1, Exp.2 and Exp.3. The same trend was observed with the TDN\%. The TDN\% values were 72.74, 70.18, 66.45 and $68.8 \%$ with feeding on control, Exp.1, Exp.2 and Exp.3 respectively, the same trends were also, with $\mathrm{ME}(\mathrm{Mcal} / \mathrm{kg}), \mathrm{ME}(\mathrm{Mj} / \mathrm{kg})$ and $\mathrm{NE}_{\mathrm{L}}(\mathrm{Mcal} / \mathrm{kg})$, there were no significant differences among other nutrients digestibility. The effect of feeding more grain or increasing rumen starch digestion on milk yield varies. Increases milk yield is often observed with increased grain feeding or increased ruminal degradation of starch, but if too rapid ruminal starch digestion causes acidosis, milk yield may decrease (Grummer, 1995). Total tract digestibility (\%) of starch was lower for the low starch diets, but ruminal digestion (\%) of starch was not affected by starch concentration. However, the corn grain treatment did not affect the productivity of cows fed the low starch diets. Oba and Allen (2003) gusted that the optimal ruminal starch digestibility is dependent on the starch content and fermentabililty of the diets.

As shown in Table (4) the $\mathrm{pH}$ values were ranged from 6.16 to 7.59 with different treatments and at all measuring times. The $\mathrm{pH}$ values decreased with advancing time $(0,2$ and $4 \mathrm{hrs})$, then increased once again at 8 hrs post-feeding. The mean value was higher $(\mathrm{P}<0.05)$ with feeding on control and lower with feeding on Exp.1, while there were no significant differences when feeding on Exp.2 and Exp.3 or between Exp.1 and Exp.2 or Exp.3. Ruminal pH is high before the morning feeding because extensive rumination and limited feed intake occur at night. After feeding the $\mathrm{pH}$ drops and the extent of this decline depends upon the size and fermentability of the meal (Russell and Wilson, 1996). The byproducts of grains that contain more fiber and less starch. In most instances the fiber of these by-products such as corn gluten feed, are highly digestible by rumen microbes. Exceptions of this include cottonseed hulls and rice hulls which are not readily digestible. In addition to containing digestible fiber many byproducts contain a greater level of protein as compared to corn (Weinder and Grant, 1994).

A higher $\mathrm{pH}$ typically favors the cellulolytic microoragnisms (Fibrobacter succinogenes, Ruminococcus flavefaciens and Ruminococcus albus) that yield a higher proportion of acetic and butyric acids. On the other hand a lower $\mathrm{pH}$ tends to favor the amylolytic microorganisms that yield a higher proportion of propionic acid. Kinetics of cellulose digestion is first order and cellulose digestion is limited by availability of substrate, not by cellulolytic capabilities of the resident microflora (Weimer, 1998). Therefore availability of fiber, the total amount and surface accessible for digestion, plays an important role in production performance. Ruminal $\mathrm{pH}$ increased linearly from 6.28 to 6.55 as ADF intake increased (Lu et al., 2008). As shown in Table (4), the mean values showed that the TVFA's concentration was significantly $(\mathrm{P}<0.05)$ higher in control group than feeding on Exp.1 or Exp.2 or Exp.3, but there was no significant effect among Exp.1, Exp.2 and Exp.3, Volatile fatty acids are the end products of microbial fermentations in the rumen. These products are absorbed across the rumen wall and utilized for biochemical synthesis, further producing products that can be served as energy sources, deposited as body fat, or synthesized into milk fat (Lu et al., 2008). Feeding more grain, or feeding grains with higher ruminal starch digestibility, generally provides the cow with more energy. Starch is fermented in the rumen to VFA (acetate, propionate and butyrate) which ate then absorbed and serve as the main sources of energy for the cow. Additionally, propionate is the primary precursor for synthesis of glucose by the liver. The amount of organic matter, particularly starch, fermented in the rumen is commonly viewed as the driver of microbial protein synthesis. Understanding starch digestion is the key to optimizing protein and energy supply to the cow, and to improving the efficiency and effectiveness of high grain diets. 
Table (1): The chemical composition of the ingredients and experimental rations.

\begin{tabular}{|c|c|c|c|c|c|c|c|c|c|c|c|c|c|c|c|c|}
\hline \multirow{2}{*}{ Item } & \multirow{2}{*}{$\mathrm{DM}$} & \multicolumn{15}{|c|}{ Chemical composition (\% as DM) } \\
\hline & & $\mathrm{OM}$ & $\mathrm{CP}$ & $\mathrm{EE}$ & $\mathrm{CF}$ & NFE & Ash & $\mathrm{NDF}$ & $\mathrm{ADF}$ & Hemi. & Cell. & ADL & $\mathrm{NFC}^{*}$ & $\mathrm{UNDF}^{1}$ & $\mathrm{ANDF}^{2}$ & $\mathrm{NDS}^{3}$ \\
\hline \multicolumn{17}{|l|}{ Ingredients } \\
\hline $\mathrm{CFM}_{0 \%}$ & 92.33 & 92.25 & 13.69 & 2.29 & 12.29 & 63.98 & 7.75 & 39.91 & 23.01 & 16.9 & 14.01 & 9.00 & 36.36 & 8.62 & 31.29 & 60.09 \\
\hline $\mathrm{CFM}_{10 \%}$ & 91.20 & 92.39 & 15.2 & 2.16 & 11.74 & 63.29 & 7.61 & 39.11 & 22.27 & 16.84 & 13.81 & 8.46 & 35.92 & 7.94 & 31.17 & 60.89 \\
\hline $\mathrm{CFM}_{15 \%}$ & 91.08 & 92.45 & 15.97 & 1.93 & 11.36 & 63.19 & 7.55 & 38.5 & 21.59 & 16.91 & 13.83 & 7.76 & 36.05 & 7.17 & 31.33 & 61.5 \\
\hline $\mathrm{CFM}_{20 \%}$ & 91.32 & 92.42 & 16.69 & 1.81 & 11.03 & 62.89 & 7.58 & 37.83 & 21.16 & 16.67 & 13.63 & 7.53 & 36.09 & 6.84 & 30.99 & 62.17 \\
\hline Corn silage & 31.60 & 89.96 & 10.67 & 3.31 & 30.62 & 45.36 & 10.04 & 44.34 & 33.02 & 11.32 & 27.67 & 5.35 & 31.64 & 5.69 & 38.65 & 55.66 \\
\hline \multicolumn{17}{|l|}{ Corn gluten } \\
\hline feed & 95.48 & 95.37 & 30.17 & 2.74 & 8.53 & 53.93 & 4.63 & 35.13 & 12.09 & 23.04 & 10.1 & 1.99 & 27.33 & 1.68 & 33.45 & 64.87 \\
\hline Rice straw & 92.36 & 83.69 & 3.87 & 1.56 & 35.48 & 42.78 & 16.31 & 74.47 & 59.84 & 14.63 & 43.24 & 16.60 & 3.79 & 29.67 & 44.80 & 25.53 \\
\hline \multicolumn{17}{|c|}{ Experimental rations } \\
\hline Control & 67.47 & 89.37 & 10.32 & 2.28 & 22.39 & 54.38 & 10.63 & 50.6 & 35.41 & 15.19 & 24.94 & 10.47 & 26.17 & 12.71 & 37.89 & 49.40 \\
\hline Exp.1 & 66.46 & 89.54 & 11.22 & 2.23 & 21.95 & 54.14 & 10.46 & 49.74 & 34.60 & 15.14 & 24.55 & 10.05 & 26.35 & 12.00 & 37.74 & 50.26 \\
\hline Exp.2 & 67.10 & 89.47 & 11.50 & 2.09 & 21.93 & 53.95 & 10.53 & 49.88 & 34.69 & 15.19 & 24.87 & 9.82 & 26.00 & 11.76 & 38.12 & 50.12 \\
\hline Exp.3 & 67.34 & 89.44 & 11.85 & 2.02 & 21.82 & 53.75 & 10.56 & 49.52 & 34.56 & 14.96 & 24.83 & 9.73 & 26.05 & 11.56 & 37.96 & 50.48 \\
\hline
\end{tabular}

Corn silage $=C S$, Corn gluten feed $=C G F$, Rice straw $=R S$.

Non fibrous carbohydrates\%=OM\% - (CP\%+NDF\%+EE \%), Calsamiglia et al., 1995.

(1)UNDF: Unavailable NDF = NDF $\times 0.01 \times A D L \times 2.4$ (Fox et al., 2000).

2) ANDF: Available NDF $=N D F-U N D F$

(3) NDS: Neutral detergent solubles $=100-N D F$.

(Control): $52 \%$ CFM ( $_{0}$ (40\% corn grain, $30 \%$ wheat bran, $0 \%$ CGF, $23 \%$ undecorticated cotton seed meal, $5 \%$ molasses, $0.5 \%$ salt and $1.5 \%$ limestone) $+20 \%$ CS + $28 \%$ RS, Exp.1: $52 \%$ CFM $_{10 \%}$ (35\% corn grain, 30\% wheat bran, 10\% CGF, 18\% undecorticated cotton seed meal, $5 \%$ molasses, $0.5 \%$ salt and $1.5 \%$ limestone $)+20 \%$ CS $+28 \%$ RS, Exp. $2: 52 \%$ CFM $15 \%(32.5 \%$ corn grain, $30 \%$ wheat bran, $15 \%$ CGF, $15.5 \%$ undecorticated cotton seed meal, $5 \%$ molasses, $0.5 \%$ salt and 1.5\% limestone) $+20 \%$ CS $+28 \%$ RS and (Exp. 3 ): $52 \%$ CFM $20 \%$ (30\% corn grain, 30\% wheat bran, $20 \%$ CGF, $13 \%$ undecorticated cotton seed meal, $5 \%$ molasses, $0.5 \%$ salt and $1.5 \%$ limestone $)+20 \%$ CS $+28 \%$ RS. 
Table (2): Average daily dry matter intake of concentrate feed mixture, corn silage and rice straw by dairy cows.

\begin{tabular}{lcccc}
\hline Item & Control & Exp.1 & Exp.2 & Exp.3 \\
\hline Average body weight (kg) & 535 & 485.7 & 491.7 & 510 \\
Kg w 0.75 & 111.2 & 103.4 & 104.4 & 107.3 \\
Concentrate : Roughage & $52.4: 47.6$ & $52.8: 47.2$ & $52.3: 47.7$ & $52.3: 47.7$ \\
Intake of dry matter: Concentrate feed mixture (CFM) & & & \\
Kg/h/d & 9.08 & 8.66 & 9.03 & 8.68 \\
\% BW & 1.70 & 1.79 & 1.84 & 1.71 \\
Intake of dry matter: Corn silage (CS) & 3.32 & & & 3.16 \\
Kg/h/d & 0.62 & 3.27 & 3.32 & 0.62 \\
\% BW & & 0.68 & 0.67 & 4.77 \\
Intake of dry matter: Rice straw (RS) & 4.93 & & & 0.94 \\
Kg/h/d & 0.92 & 4.46 & 4.93 & 1.00 \\
\% BW & & 0.92 & & 17.61 \\
Total dry matter intake (DMI) & 17.32 & 16.39 & 3.28 & 3.26 \\
Kg/h/d & 3.24 & 3.38 & 3.51 & \\
\% BW & & & & \\
\hline
\end{tabular}

Table (3): Effect of the experimental rations on the digestion coefficients and feeding values by dairy cows.

\begin{tabular}{lccccc}
\hline Item & Control & Exp.1 & Exp.2 & Exp.3 & SEM \\
\hline Nutrient digestibility (\%): & & & & & \\
DM & 76.20 & 74.15 & 70.53 & 72.46 & 1.847 \\
OM & 78.64 & 75.74 & 72.04 & 74.72 & 1.960 \\
CP & $74.60^{\mathrm{a}}$ & $67.88^{\mathrm{b}}$ & $62.12^{\mathrm{b}}$ & $64.57^{\mathrm{b}}$ & 1.916 \\
EE & 86.21 & 84.68 & 76.54 & 78.00 & 1.745 \\
CF & 64.76 & 68.37 & 57.10 & 58.21 & 4.478 \\
NFE & 84.81 & 79.97 & 80.05 & 83.46 & 3.046 \\
NDF & 71.23 & 69.96 & 69.79 & 69.21 & 2.526 \\
ADF & 69.62 & 71.91 & 70.70 & 68.63 & 2.640 \\
Hemi. & 74.97 & 65.33 & 67.71 & 70.77 & 6.449 \\
Cell. & 76.88 & 73.17 & 73.87 & 75.93 & 2.714 \\
ADL & $52.34^{\mathrm{bc}}$ & $68.81^{\mathrm{a}}$ & $62.67^{\mathrm{ab}}$ & $49.99^{\mathrm{c}}$ & 3.574 \\
NFC & $93.88^{\mathrm{a}}$ & $89.20^{\mathrm{ab}}$ & $80.40^{\mathrm{b}}$ & $89.52^{\mathrm{ab}}$ & 3.248 \\
Feeding value: & & & & \\
TDN\% & $72.74^{\mathrm{a}}$ & $70.18^{\mathrm{ab}}$ & $66.45^{\mathrm{b}}$ & $68.80^{\mathrm{ab}}$ & 1.798 \\
DCP\% & 7.70 & 7.62 & 7.14 & 7.65 & 0.261 \\
ME (Mcal/kg) & $2.59^{\mathrm{a}}$ & $2.50^{\mathrm{ab}}$ & $2.37^{\mathrm{b}}$ & $2.45^{\mathrm{ab}}$ & 0.064 \\
ME (Mj/kg) & $10.83^{\mathrm{a}}$ & $10.45^{\mathrm{ab}}$ & $9.89^{\mathrm{b}}$ & $10.24^{\mathrm{ab}}$ & 0.268 \\
NE $(\mathrm{Mcal} / \mathrm{kg})^{*}$ & $1.66^{\mathrm{a}}$ & $1.60^{\mathrm{ab}}$ & $1.51^{\mathrm{b}}$ & $1.57^{\mathrm{ab}}$ & 0.044 \\
DDM\% & $61.51^{\mathrm{a}}$ & $59.02^{\mathrm{ab}}$ & $56.44^{\mathrm{b}}$ & $58.14^{\mathrm{ab}}$ & 1.415 \\
RFV & 154.63 & 154.81 & 153.55 & 147.40 & 6.911 \\
\hline
\end{tabular}

$a, b$ and $c:$ Means within the same row with different superscripts are significantly different $(p<0.05)$.

${ }^{*} N E_{L}(\mathrm{Mcal} / \mathrm{kg})=(T D N \% \times 0.0245)-0.12(\mathrm{NRC}, 2001)$.

${ }^{* *} D D M \%$ of $D M=88.9-0.779 \times(A D F \%$ of DM) (Schroeder, 1996).

${ }^{* * * *} R F V=D M I x D D M / 1.29$ (Schroeder, 1996). 
Egyptian J. Nutrition and Feeds (2018)

Table (4): Effect of feeding experimental rations on some rumen liquor parameters at different times of sampling.

\begin{tabular}{lcccccc}
\hline Item & Hours & Control & Exp.1 & Exp.2 & Exp.3 & SEM \\
\hline \multirow{4}{*}{ pH-Values } & 0 & 7.59 & 7.29 & 7.36 & 7.49 & 0.123 \\
& 2 & 6.67 & 6.16 & 6.63 & 6.30 & 0.196 \\
& 4 & 6.78 & 6.37 & 6.37 & 6.53 & 0.212 \\
& 8 & $6.86^{\mathrm{a}}$ & $6.21^{\mathrm{b}}$ & $6.57^{\mathrm{a}}$ & $6.58^{\mathrm{a}}$ & 0.099 \\
& Means & $6.97^{\mathrm{a}}$ & $6.51^{\mathrm{b}}$ & $6.73^{\mathrm{ab}}$ & $6.73^{\mathrm{ab}}$ & 0.082 \\
& 0 & $3.23^{\mathrm{ab}}$ & $2.83^{\mathrm{b}}$ & $3.60^{\mathrm{a}}$ & $3.30^{\mathrm{ab}}$ & 0.162 \\
Total VFA's & 2 & $5.73^{\mathrm{a}}$ & $4.93^{\mathrm{b}}$ & $4.17^{\mathrm{c}}$ & $5.20^{\mathrm{ab}}$ & 0.210 \\
(ml eq /100ml) & 4 & 4.30 & 4.27 & 4.33 & 4.47 & 0.076 \\
& 8 & $4.47^{\mathrm{a}}$ & $4.30^{\mathrm{a}}$ & $3.93^{\mathrm{ab}}$ & $3.73^{\mathrm{b}}$ & 0.161 \\
& Means & $4.43^{\mathrm{a}}$ & $4.08^{\mathrm{b}}$ & $4.01^{\mathrm{b}}$ & $4.18^{\mathrm{b}}$ & 0.080 \\
& 0 & 16.33 & 16.33 & 14.00 & 14.67 & 1.00 \\
$\mathrm{NH}_{3^{-}} \mathrm{N}$ & 2 & 8.33 & 8.33 & 6.67 & 9.33 & 0.782 \\
$(\mathrm{mg} / 100 \mathrm{ml})$ & 4 & $11.33^{\mathrm{a}}$ & $5.67^{\mathrm{b}}$ & $6.33^{\mathrm{b}}$ & $7.33^{\mathrm{b}}$ & 0.601 \\
& 8 & $6.00^{\mathrm{b}}$ & $10.67^{\mathrm{a}}$ & $6.67^{\mathrm{b}}$ & $7.00^{\mathrm{b}}$ & 1.027 \\
& Means & $10.50^{\mathrm{a}}$ & $10.25^{\mathrm{a}}$ & $8.42^{\mathrm{b}}$ & $9.58^{\mathrm{ab}}$ & 0.435 \\
& & $36.63^{\mathrm{a}}$ & $25.58^{\mathrm{c}}$ & $30.92^{\mathrm{b}}$ & $30.78^{\mathrm{b}}$ & 1.512 \\
\hline
\end{tabular}

$a, b$ and $c:$ Means within the same raw with different superscripts are significantly different $(p<0.05)$.

*\% eNDF $=(p H-5.425) / 0.04229$ (Fox et al., 2000).

Data presented in Table (4), showed that ruminal $\mathrm{NH}_{3}-\mathrm{N}$ concentrations at $0,2,4$ and 8 hrs postfeeding was ranged from 5.67 to $16.33 \mathrm{mg} / \mathrm{ml}$ rumen liquor with different treatments. The optimal concentration of ruminal $\mathrm{NH}_{3}-\mathrm{N}$ required to maximize microbial protein synthesis are controversial, bur 5 $\mathrm{mg} / \mathrm{dl}$ of $\mathrm{NH}_{3}-\mathrm{N}$ maximized microbial protein synthesis (Satter and Slyter, 1974). Under in vitro conditions, $\mathrm{NH}_{3}-\mathrm{N}$ started to accumulate when dietary $\mathrm{N}$ concentrations equivalent to $11-14 \% \mathrm{CP}$ (DM basis) were added to fermenters (Satter and Slyter, 1974). Karsli and Russell (2002) have indicated that concentrations of 11 to $13 \% \mathrm{CP}$ in diets were adequate to contain optimal microbial protein synthesis. Several studies have reported increased utilization of ruminal $\mathrm{NH}_{3}-\mathrm{N}$ for microbial protein synthesis when diets contained readily digestible carbohydrate rather than starch in high fiber diets (Karsli and Russell, 2002). Microbial N synthesis was highest when highly ruminally available nonstructural carbohydrates (NSC) were combined with highly ruminally available protein, and lowest when highly ruminally available NSC were combined with poorly ruminally available protein. As shown in Table (4), the effective neutral detergent fiber (eNDF) values ranged from 25.58 to $36.63 \%$. The eNDF was higher $(\mathrm{P}<0.05)$ with feeding on control than feeding on Exp.1 or Exp. 2 or Exp.3. Effective NDF (eNDF) is the percentage of the NDF effective in stimulating chewing and salivation, rumination and rumen motility (Russell et al., 1992). Effective NDF was calculated to estimate adjustments in ruminal $\mathrm{pH}$ useful when eNDF was below $30 \%$. Fiber digestion is at normal levels (pH about 6.2 optimal) when eNDF is at least $20 \%$. As forage NDF is replaced by non forage NDF total NDF digestibility seems to decrease as a result of increasing negative associative effects (Firkins, 1997). Similarly, as the ratio of forage NDF to ruminal degradable starch (RDS) decreases below 1:1, Poor et al. (1993) suggested that ruminal function was comprised by excessive acidity in the rumen. The by-product of starch digestion is the production of stronger acids as compared to weaker acids produced during fiber digestion. The production of stronger acids as a result of starch digestion causes a reduction in rumen $\mathrm{pH}$. As the $\mathrm{pH}$ begins to decline, the rumen environment reaches a point where it is no longer suitable for the fiber digesting bacteria to digest fiber efficiency. This change in rumen environment results in a reduction in how fast fiber is digested. When balancing rations that require greater than $0.5 \%$ body weight as supplemental high starch grains such as corn, supplementation adjustments should be made because of the expectations for a reduction in forage intake. In general, to maximize the fermentation of forage fiber and NSC (sugars and starches) in the rumen, while maintaining rumen $\mathrm{pH}$ above 6.2. This requires an understanding to the nutritional needs of the rumen bacteria. The fiber-digesting bacteria require a constant supply of $\mathrm{NH}_{3}$ to grow and manufacture microbial protein. Ammonia in the rumen comes from the fermentation-soluble and degradable protein plus recycled $\mathrm{NH}_{3}$ from the saliva. 


\section{Maklad et al.}

Data presented in Table (5) showed the ruminal fibrolytic bacteria count was almost higher $(\mathrm{P}<0.05)$ with feeding on Exp.1, Exp.2 and Exp.3 than feeding on control by advancing time post-feeding to record the highest $(\mathrm{P}<0.05)$ values at 4 hrs. post-feeding value of fibrolytic bacteria was higher $(\mathrm{P}<0.05)$ with feeding on Exp. 2 than feeding on control or Exp.1 or Exp.3.

Table (5): Effect of feeding experimental rations on some microbial count in the rumen liquor.

\begin{tabular}{|c|c|c|c|c|c|c|}
\hline Item & Hours & Control & Exp.1 & Exp.2 & Exp.3 & SEM \\
\hline Fibrolytic & 0 & $5.00^{b}$ & $7.17^{\mathrm{a}}$ & $6.57^{\mathrm{ab}}$ & $8.47^{\mathrm{a}}$ & 0.580 \\
\hline bacteria & 2 & $8.00^{\mathrm{b}}$ & $9.00^{\mathrm{b}}$ & $16.00^{\mathrm{a}}$ & $6.83^{b}$ & 1.530 \\
\hline (Microbial & 4 & $7.33^{b}$ & $5.67^{b}$ & $22.17^{\mathrm{a}}$ & $11.00^{\mathrm{b}}$ & 1.652 \\
\hline count x 100000 & 8 & 10.67 & 10.67 & 14.33 & 12.33 & 2.088 \\
\hline CFU/ml) & Means & $7.750^{\mathrm{b}}$ & $8.125^{\mathrm{b}}$ & $14.767^{\mathrm{a}}$ & $9.658^{b}$ & 0.781 \\
\hline Amylolytic & 0 & 4.17 & 4.10 & 3.67 & 3.67 & 0.708 \\
\hline bacteria & 2 & $6.73^{\mathrm{a}}$ & $3.13^{\mathrm{ab}}$ & $1.93^{\mathrm{b}}$ & $3.20^{\mathrm{ab}}$ & 1.273 \\
\hline (Microbial & 4 & $5.67^{\mathrm{a}}$ & $4.73^{\mathrm{ab}}$ & $2.97^{\mathrm{b}}$ & $2.90^{\mathrm{b}}$ & 0.703 \\
\hline count x 100000 & 8 & $8.47^{\mathrm{a}}$ & $3.78^{\mathrm{ab}}$ & $3.00^{\mathrm{b}}$ & $6.70^{\mathrm{ab}}$ & 1.386 \\
\hline $\mathrm{CFU} / \mathrm{ml})$ & Means & $6.258^{\mathrm{a}}$ & $3.938^{b}$ & $2.892^{b}$ & $4.117^{b}$ & 0.533 \\
\hline \multicolumn{7}{|c|}{ Microbial protein production ( $\mathrm{Ng} /$ day) } \\
\hline $\begin{array}{l}\text { DM intake }(\mathrm{Kg} / \\
\mathrm{NE}_{\mathrm{L}} \text { (Mcal/kg }\end{array}$ & $\begin{array}{l}\text { /dav) } \\
\text { et) }\end{array}$ & $\begin{array}{l}17.323 \\
1.662^{\mathrm{a}}\end{array}$ & $\begin{array}{l}16.393 \\
1.600^{\mathrm{ab}}\end{array}$ & $\begin{array}{l}17.276 \\
1.508^{b}\end{array}$ & $\begin{array}{l}16.608 \\
1.565^{\mathrm{ab}}\end{array}$ & $\begin{array}{l}0.830 \\
0.044\end{array}$ \\
\hline $\mathrm{NE}_{\mathrm{L}}$ Intake $(\mathrm{Mc}$ & 1/day) & 28.777 & 26.180 & $\begin{array}{c}25.913 \\
198667\end{array}$ & 25.980 & $\begin{array}{l}1.229 \\
8.865\end{array}$ \\
\hline
\end{tabular}

$a, b$ and $c:$ Means within the same row with different superscripts are significantly different $(p<0.05)$.

$* M C P N g /$ day $=-6.24+\left(8.54 x N E_{L}\right.$ intake Mcal/day $)-\left(0.024 x N E I_{L}^{2}\right)$, (Oldick et al, 1999).

On the other hand, the ruminal amylolytic bacteria count was almost higher $(\mathrm{P}<0.05)$ with feeding on control at $2 \mathrm{hr}$ up to $8 \mathrm{hrs}$ post-feeding than feeding on Exp.2, while there was no differences among control or Exp. 1 or Exp.3. The mean value was the highest $(\mathrm{P}<0.05)$ with feeding on the control than feeding on Exp.1 or Exp.2 or Exp.3.

As shown in Table (5), the calculated microbial protein production (g/day) was similar with feeding on the different experimental rations. Many mammals are herbivorous and consume plant material high in cellulose. Consequently these animals have evolved a close symbiotic relationship with the microorganisms which reside in their gut which aid the digestion of highly fibrous plant material for the host. A high fiber diet provides not only substrates that favor the growth of cellulolytic microbes, but also increase salivation through eating and ruminating. Salivation through its buffering capacity further increases ruminal $\mathrm{pH}$ that favors the growth of cellulolytic microbes ( $\mathrm{Lu}$ et al., 2008). Consideration of the nutrients required to support microbial growth indicates that major source of energy used by ruminal microorganisms is the mono saccharides, which are derived from the ruminal catabolism of ingested soluble and structural carbohydrates (Beever and Cattrill, 1994). A fermentable carbohydrate that releases energy at the same rate as $\mathrm{N}$ is released from dietary $\mathrm{N}$ source is also required for the most efficient utilization of nutrients by rumen microbes (Sinclair et al., 1995). It seems that diets containing a mixture of structural and non-structural carbohydrate sources increase microbial protein synthesis and the efficiency of microbial protein synthesis because of an improved ruminal environment for more divers ruminal bacteria species and increased amount and type of substrates, available for microbial protein synthesis. In cows fed a high forage diet, the microbial population consists of a low number of lactate producers (starch digesters) and lactate users (convert lactate to acetate and propionate), and a large number of cellulolytic bacteria (Dann et al., 1999).

As shown in Table (6) the leptin concentration was increased with advancing time from 0 up to $2 \mathrm{hrs}$. post feeding then decreased at $4 \mathrm{hrs}$ and increased again at $8 \mathrm{hrs}$. post-feeding. The mean value was increased significantly $(\mathrm{P}<0.05)$ with feeding on Exp.1, Exp.2 and Exp.3 than feeding the control. The insulin concentrations were having the same trend with advancing times as shown in Table (6). 
Egyptian J. Nutrition and Feeds (2018)

Table (6): Effect of experimental rations on some blood parameters.

\begin{tabular}{|c|c|c|c|c|c|c|}
\hline Item & Hours & Control & Exp.1 & Exp.2 & Exp.3 & SEM \\
\hline \multirow{7}{*}{$\begin{array}{c}\text { Non-estrified fatty } \\
\text { acids (NEFA), ml } \\
\text { Eq/L }\end{array}$} & 0 & 0.20 & 0.25 & 0.23 & 0.26 & \\
\hline & 2 & 0.26 & 0.19 & 0.24 & 0.23 & \\
\hline & 4 & 0.22 & 0.25 & 0.46 & 0.36 & \\
\hline & 8 & 0.85 & 0.87 & 0.90 & 0.96 & \\
\hline & Mean & 0.38 & 0.39 & 0.46 & 0.45 & 0.049 \\
\hline & 0 & 0.90 & 1.00 & 1.47 & 2.10 & \\
\hline & 2 & 3.37 & 3.43 & 3.73 & 3.93 & \\
\hline \multirow[t]{5}{*}{ Leptin, ng/ml } & 4 & 3.63 & 3.40 & 3.37 & 3.87 & \\
\hline & 8 & 3.17 & 4.13 & 3.90 & 3.90 & \\
\hline & Mean & $2.77^{\mathrm{c}}$ & $2.99^{\mathrm{bc}}$ & $3.12^{\mathrm{b}}$ & $3.45^{\mathrm{a}}$ & 0.084 \\
\hline & 0 & 0.19 & 0.19 & 0.22 & 0.23 & \\
\hline & 2 & 0.24 & 0.23 & 0.28 & 0.27 & \\
\hline \multirow[t]{4}{*}{ Insulin, $\mathrm{ng} / \mathrm{ml}$} & 4 & 0.23 & 0.20 & 0.19 & 0.24 & \\
\hline & 8 & 0.24 & 0.27 & 0.25 & 0.28 & \\
\hline & Mean & $0.23^{\mathrm{b}}$ & $0.23^{\mathrm{b}}$ & $0.23^{b}$ & $0.25^{\mathrm{a}}$ & 0.006 \\
\hline & 0 & 5.81 & 5.92 & 6.42 & 6.14 & \\
\hline \multirow{6}{*}{$\begin{array}{c}\text { Free fatty acids } \\
\text { (FFA), mg\% }\end{array}$} & 2 & 8.30 & 8.96 & 8.45 & 9.79 & \\
\hline & 4 & 10.96 & 11.21 & 11.15 & 11.18 & \\
\hline & 8 & 11.18 & 11.34 & 10.92 & 10.93 & \\
\hline & Mean & $9.06^{\mathrm{b}}$ & $9.36^{\mathrm{ab}}$ & $9.23^{\mathrm{ab}}$ & $9.51^{\mathrm{a}}$ & 0.105 \\
\hline & 0 & 117.85 & 155.52 & 138.49 & 149.78 & \\
\hline & 2 & 123.44 & 117.63 & 132.38 & 151.82 & \\
\hline \multirow[t]{5}{*}{ Glucose, $\mathrm{mg} \%$} & 4 & 122.44 & 114.90 & 151.27 & 142.71 & \\
\hline & 8 & 184.93 & 185.53 & 180.92 & 166.94 & \\
\hline & Mean & 137.17 & 143.40 & 150.77 & 152.81 & 5.811 \\
\hline & 0 & 71.32 & 65.96 & 69.11 & 67.19 & \\
\hline & 2 & 57.32 & 65.23 & 43.74 & 40.68 & \\
\hline \multirow[t]{5}{*}{ Cholestrol, mg\% } & 4 & 46.35 & 46.51 & 43.97 & 40.55 & \\
\hline & 8 & 33.28 & 31.82 & 48.91 & 46.86 & \\
\hline & Mean & 52.07 & 52.38 & 51.43 & 48.82 & 2.316 \\
\hline & 0 & 328.95 & 343.73 & 327.84 & 308.26 & \\
\hline & 2 & 291.76 & 218.82 & 208.36 & 287.44 & \\
\hline \multirow[t]{4}{*}{ Triglycerides, mg\% } & 4 & 204.91 & 169.38 & 106.06 & 110.15 & \\
\hline & 8 & 160.13 & 193.64 & 142.58 & 130.67 & \\
\hline & Mean & $246.44^{\mathrm{a}}$ & $231.39^{\mathrm{a}}$ & $196.21^{b}$ & $209.13^{b}$ & 7.279 \\
\hline & 0 & 5.69 & 4.37 & 4.19 & 4.32 & \\
\hline \multirow{6}{*}{$\begin{array}{l}\text { Total protein (T.P), } \\
\mathrm{g} \%\end{array}$} & 2 & 6.47 & 6.27 & 5.77 & 4.26 & \\
\hline & 4 & 4.23 & 5.41 & 4.91 & 7.58 & \\
\hline & 8 & 5.29 & 8.01 & 6.18 & 6.12 & \\
\hline & Mean & $5.42^{b}$ & $6.01^{\mathrm{a}}$ & $5.26^{\mathrm{c}}$ & $5.57^{\mathrm{b}}$ & 0.054 \\
\hline & 0 & 5.32 & 6.59 & 9.15 & 9.09 & \\
\hline & 2 & 13.09 & 11.60 & 14.32 & 17.23 & \\
\hline \multirow[t]{3}{*}{ Urea, mg\% } & 4 & 17.53 & 18.68 & 23.39 & 25.10 & \\
\hline & 8 & 30.48 & 37.83 & 39.85 & 41.52 & \\
\hline & Mean & $16.60^{\mathrm{c}}$ & $18.67^{\mathrm{b}}$ & $21.68^{\mathrm{a}}$ & $23.24^{\mathrm{a}}$ & 0.653 \\
\hline
\end{tabular}

$a, b$ and $c:$ Means within the same row with different superscripts are significantly different $(p<0.05)$.

The free fatty acids (FFA's) concentrations were increased with advancing time from 0 to 8 hrs post feeding as shown in Table (6). The mean value was higher $(\mathrm{P}<0.05)$ with feeding on Ex.3 than feeding on control, but there were no significant differences when feeding control or Exp.1 and Exp.2. In the reversal situs, triglycerides concentrations were decreased with advancing time from 0 to $8 \mathrm{hrs}$. post feeding as shown in Table (6). The mean values were higher $(\mathrm{P}<0.05)$ with feeding on control and Exp.1 than feeding on Exp.2 and Exp.3 as shown in Table (6). There were no significant effects on the mean values of cholesterol concentrations with feeding the experimental rations. The total protein concentrations were ranged from 4.19 to $8.01 \mathrm{~g} / 100 \mathrm{ml}$ with feeding on the experimental rations at all times, as shown in Table 6. The mean value was higher $(\mathrm{P}<0.05)$ with feeding on Exp.1 than feeding on control, Exp.2 and 


\section{Maklad et al.}

Exp.3.The urea concentrations were increased with Exp. 1 or Exp. 2 or Exp. 3 than feeding on control at all times, as shown in Table (6).There was no significant effect with feeding experimental rations on glucose or non-esterified fatty acids (NEFA) concentrations. The results in Table (6) shown that, the highest concentration of glucose, insulin and leptin were observed with feeding on Exp.2 and Exp. 3 compared with feeding on control or Exp.1, while the highest concentrations of total protein and triglycerides and lowest concentrations of urea and NEFA were with feeding on control and Exp.1 compared with feeding on Exp.2 and Exp.3. Ruminant animals maintain low blood glucose concentration $(<70 \mathrm{mg} / \mathrm{dl})$ compared to non-ruminant animals $(>0.85 \mathrm{mg} / \mathrm{dl})$. Low blood glucose is the result of microbial fermentation of dietary sugars and starches to the VFA propionate, with minimal glucose being presented to the small intestine for absorption. In contrast, ruminants maintain higher blood glucose concentrations more similar to that of non-ruminant animals. Hyperglycemic response (blood glucose concentrations $>200 \mathrm{mg} / \mathrm{dl}$ ) in response to even minimal stress situations. Elevated blood glucose can be somewhat explained by studies showing a sluggish insulin response and moderate insulin resistance, somewhat similar to diabetes condition (Cebra et al., 2001). Insulin was positively correlated with glucose and total protein, but negatively correlated with total cholesterol. Insulin regulates the use of glucose and therefore glucose uptake by cells depends on the hormone insulin (Wettemann et al., 2003). In early lactation, when cows are in negative energy balance, they may develop ketosis and experience depressed insulin and glucose levels, with elevated ketones, free fatty acids, and cholesterol in the blood. There is a positive relationship between nutrient intake and concentration of leptin in plasma of cattle, as increased plane of nutrition is associated with increased circulating leptin concentrations (Leon et al., 2004). Glucose is utilized by all animal cells to produce energy (Richards et al., 1995), glucose concentration was significant and positively correlated with total protein but negatively correlated to urea. Total cholesterol was positively correlated with urea. Due to poor nutritional status and body condition score (BCS) of the experimental cows, relatively less fat was available to be metabolized to provide energy. Thus more protein was metabolized to meet the energy requirements and this elevated the urea and creatinine concentrations (Damptey et al., 2013). In most circumstances glucose requirement can be predicted reasonably well from ME intake (Reynolds, 1995), or on the basis of milk yield (milk lactose yield/ 0.7). On the other hand, the concentration of plasma insulin decreases dramatically as calving approaches and remains low in the first week postpartum. The concentration of plasma somatotropin increases dramatically and rapidly postpartum. This decrease in insulin combined with a decrease in sensitively of adipose tissue to insulin and the increase in somatotropin results in a decrease in the synthesis of triglycerides in adipose and favors their mobilization (Lanna and Bauman, 1990). Therefore, there is a resulting increase in plasma NEFA at calving. The somatotropin, in concert with elevated cortisol, stimulates the liver to produce more glucose.

The present study suggested that corn grain and undecorticated cottonseed meal can be replaced by $15 \%$ corn gluten feed are often considered providing the proper amounts of ruminally fermentable carbohydrates are critical to optimizing ruminal fermentation and generating volatile fatty acids and microbial protein for energy and amino acid use by the lactating Friesian cows.

\section{REFERENCES}

Abshire, R.L. (1977). Evaluation of a new presumptive medium for group d streptococci. Applied and Environmental Microbiology, 1149-1155.

Ahima, R.S. and J.S. Flier (2000). Leptin. Ann Rev Physiol 62, 413-437.

Allain, C.C., L.S. Poon, C.S. Chan, W.S. Richmond and P.C. Fu (1974). Enzymatic determination of total serum cholesterol. Clin. Chemi., 20: 470-475.

AOAC (1990). Association of Official Analytical Chemists. Official Methods of Analysis. $15^{\text {th }}$ Ed., Washington DC.

Beever, D. E. and B. R. Cottrill (1994). Protein systems for feeding ruminant Livestock: A European Assessment. J. Dairy Sci., 77: 2031.

Calsamiglia, S.; M. D. Stern and J. L. Firkins (1995). Effects of protein source on nitrogen metabolism in continuous culture and intestinal digestion in vitro. J. Anim. Sci., 73: 1819.

Cebra, C. K.; S. J. Tornquist, R. J. Van Saun and B. B. Smith (2001). Glucose tolerance testing in Ilams and alpacas Am. J. Vet. Res. 62 (5): 682. 
Cohen, B; D. Novick and M. Rubinstein (1996). Modulation of insulin activities by leptin.Science 274, 1185- 1188.

Conway, E.F. (1957). Microdiffusion Analysis and Volumetric Error. Rev. Ed. Lock wood, London.

Cunningham, J.G. (1992). Textbook of Veterinary Physiology W.B. Saunders, London, pp 655- 699.

Damptey, J. K.; F. Y Obese, G. S. Aboagye and R. A. Ayizanga (2013). Correlations among concentration of some metabolic hormones and nutritionally-related metabolites in beef cows. Journal of Animal and Feed Research, 3 (4): 176.

Dann, H. M., G. A. Vagra and D. E. Putnam (1999). Improving energy supply to late gestation and early postpartum dairy cows. Journal of Dairy Science, 82: 1765.

Duncan, D. B. (1955). Multiple Range and Multiple F Test. Biometrics, 11: 10.

Faweett, J.K. and J.G. Scott (1960). A rapid precise method for the determination of urea. Journal of Clinical Pathology, 13: 156- 159.

Firkins, J. L. (1997). Effects of feeding nonforage fiber sources on site of fiber digestion. J. Dairy Sci., 80: 1438 .

Fossati, P. and L. Prencipe (1982). Serum triglycerides determined colorimetrically with an enzyme that produces hydrogen peroxide. Clinical Chemi., 28: 2077- 2080.

Fox, D. G. ; T. P. Tylutki, M. E. Van Amburgh, L. E. Chase, A. N. Pell, T. R. Overton, L. O. Tedeschi, C. N. Rasmussen and V. M. Durbal (2000). The net carbohydrate and protein system for evaluating herd nutrition and nutrient excretion. Animal science Mimeo 213, Department of animal science, Cornell University, 130 Morrison Hall, Ithaca, New york 14853.

Gornall, A.G., C.J. Bardawill and M.M. David (1949). Determination of serum protein by means of the biuret reaction. J. Biol. Chem., 177: 751- 766.

Grant, R. J. (1997). Interaction among forages and nonforage fiber sources. J. Dairy Sci., 80: 1438.

Grummer, R. R, (1995). Impact of changes in organic nutrient metabolism of feeding the transition dairy cow. J. Anim. Sci., 73: 2820.

Hutjens, M. F. (2010). Feeding economic for 2010. Proc. Four state dairy Nutrition and Management Conference. pp. 27.

Karsli, M. A., and J. R. Russell (2002). Effects of source and concentration of nitrogen and carbohydrate on ruminal microbial protein synthesis. Turk J. Vet. Anim. Sci., 26: 201.

Kossila, V. L. (1981). Reviews on the potential for be utilization of crop residues and agro-industrial byproducts in developing countries. FAO, Rome, Italy.

Lanna, D. P. D, and D. E. Bauman (1990). Effect of somatotropin, insulin and glucorticocoid on Lypolysis in chronic cultures of adipose tissue from Lactating cows.J. Dairy Sci., 82: 60.

Leon, H. V.; J. Hernandez-Ceron, D. H. Keisler and C. G. Gutierrez (2004). Plasma concentration of leptin, insulin - like growth factor -1 and insulin in relation to changes in body condition score in heifers. Journal of Animal Science, 82: 445.

Lu, C. D.; J. R. Kawas and O. G. Mahgoub (2008). Recent advancements in fiber digestion and utilization in goats. Tropical and Subtropical Agroecosystems, 9: 65.

Maklad, Eman H.M.; M. Y. El-Ayek, A. M. Abd El-Khabir and K. M. I. Sharaf. (2017). Effect of feeding different levels of corn gluten feed on milk production and economic efficiency in Friesian dairy cows rations. Journal of Animal and Poultry Production, Mansoura Univ., 8(10): 419-424.

NRC (1989).National Research Council Nutrient requirements of dairy cattle. 6th Ed. Natl. Acad. Sci. Washington, DC.

NRC (2001). National Research Council Nutrient requirements of dairy cattle. $7^{\text {th }}$ Rev. ed. National Academy Press, Washington, DC.

Oba, M. and M. S. Allen (2003b). Effects of corn grain conservation method on ruminal digestion kinetics for lactating dairy cows at two dietary starch concentration. J. Dairy. Sci., 86: 184. 


\section{Maklad et al.}

Oldick, B. S.; J. L. Firkins and N. R. St-Pierre (1999). Estimation of microbial nitrogen flow to the duodenum of cattle based on dry matter intake and diet composition. J. Dairy Sci., 82: 1497.

Poor, M. H.; J. A. Moore, R. S. Swingle, T. P. Eck and W. H. Brown (1993). Response of lactating Holstein cows to diets varying in fiber source and ruminal starch degradability. J Dairy Sci., 76: 2235.

Reynolds, C. K. (1995). Quantitative aspects of liver metabolism in ruminants. Pages 351-371 in Ruminant physiology: Digestion, metabolism, growth and reproduction: Proc. $8^{\text {th }}$ Int. Symp. Ruminant physiol. W.V. Engel hardt, S. Leonhard-Marek, G. Breves and D. Giesecke, ed. Ferdinand Enke Verlag, Stuttgardt, Germany.

Richards, M. W.; L. H. Spicer and R. P. Wetteman (1995). Influence of diet and ambient temperature on bovine serum insulin - like growth factor - 1 and thyroxine: relationships with non - esterified fatty acids, glucose, insulin, Luteinizing hormone and progesterone. Animal Reproduction Science, 37: 267.

Russell, J. B. and D. B. Wilson (1996). Why are ruminal cellulolytic bacteria unable to digest cellulose at low PH? J. Dairy Sci., 79:1503.

Russell, J. B.; J. D. O' Connor, D. G. Fox, P. Van Soest and C. J. Sniffen (1992). A net carbohydrate and protein system for evaluating cattle diets.1. Ruminal fermentation. J. Anim. Sci., 70: 3551.

Satter, L. D. and L. L. Slyter (1974). Effect of ammonia concentration on rumen microbial protein production in vitro. Br. J. Nutr., 32: 199.

Schneider, B.H. and W.P. Flatt (1975). The evaluation of feeds through Digestibility Experiments. The University of Georgia Press Athens, 30602.

Schroeder, J.W. (1996). Quality forage for maximum production and return. NDSU Extension service , North Dakota State University

Shaver, R. D. (2008). Coping with high corn prices: low starch diets and lactation performance by dairy cows. Pages 128-133 in Proc. $6^{\text {th }}$ Mid-Atlantic Nutr. Conf. Timonium, MD.

Sinclair, L. A.; P. C. Gamworthy, J. R. Newbold and P. J. Buttery (1995). Effect of synchronizing the rate of dietary energy and nitrogen in diets with a similar carbohydrate composition on rumen fermentation and microbial protein synthesis in sheep. J. Agric. Sci., 124: 463.

Snedecor, G. W. and W. G. Cochran (1982). Statistical Methods. $7^{\text {th }}$ Ed. Iowa State Univ. Press. Ames. Iowa.

Trinder, P. (1969). Determination of glucose in blood using glucose oxidase wite an alternative oxygen acceptor. Ann. Clin. Biochem, 6: 24-27.www.grains.org

Van Keulen, J. and B.A. Young (1977). Evaluation of acid insoluble ash as a digestibility studies. J. Anim. Sci., 44: $282 . \propto$

Varel, V.H. and H.G. Jung (1986). Influence of forage phenolics on ruminal fibrolytic bacteria and in vitro fiber degradation. Applied and Environmental Microbiology, 275- 280.

Wahlberg, M. L. (2009). Alternative feeds for beef cattle. Virginia Polytechnic Institute and State University.

Warner, A.C.I. (1964). Production of volatile fatty acids in the rumen, methods of measurements. Nutr. Abst. \& Rev., 34: 339.

Weimer, P. J. (1998). Manipulating ruminal fermentation: a microbial perspective. J. Anim. Sci., 76: 3114.

Weinder, S. J. and R. J. Grant (1994). Soy hulls as a replacement for forage fiber in diets for lactating dairy cows. J. Dairy Sci., 77: 513.

Wetteman, R. P.; C. A. Lent, N. H. Ciccioli, F. J. White and I. Rubio (2003). Nutritional and suckling mediated anovulation in beaf cows. Journal of Animal Science, 81 (E.suppl.2): E48-E59.

Zollner, N. and K. Kirsch (1962). A colorimetric method to determine total lipid. Z. Ges, exp. Med., 135. 
تأثير التفذية على مستويات مختلفة من الجلوتوفيد على معاملات الهضم ، المسأكول ، بعض قياسـات الدم وبعض مقاييس الكرش في علائق الأبقار الفريزيان الحلابة.

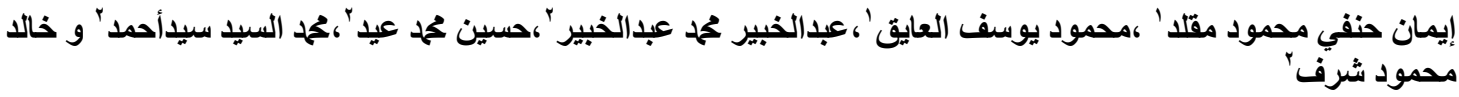 \\ ' قسم إنتاج الحيوان، كلية الزيراعة، جامعة المنصورة، مصر.

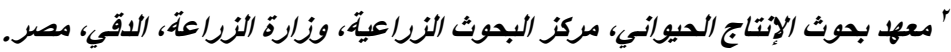

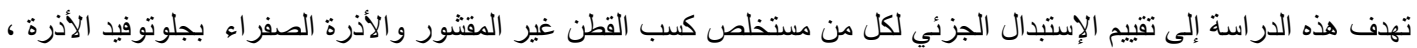

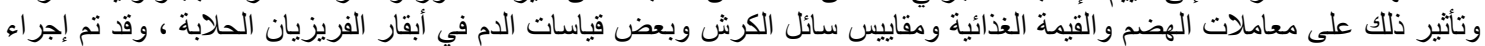

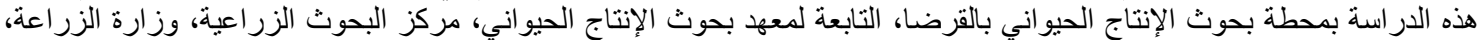

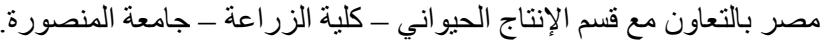
وقد إثتملت الدراسة على أربعة مجمو عات تحتوي كل مجموعة على ثلاث أبقار فريزيان حلابة في المو اسم من الثاني إلى الر ابع و

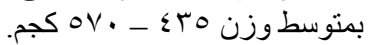
وتم تكوين أربعة أنواع من العلف المُركز كما يلي:-

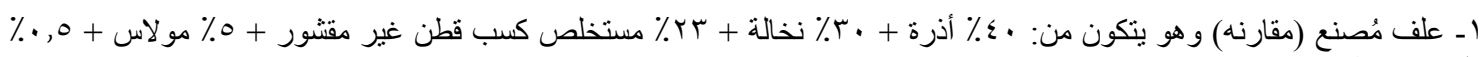

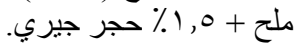

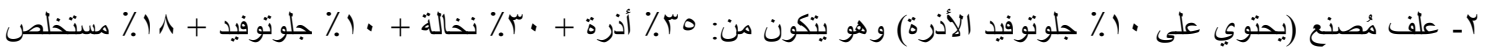

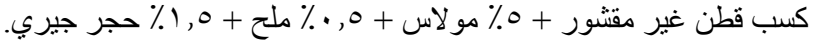

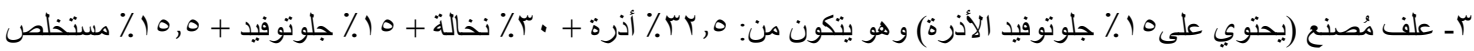

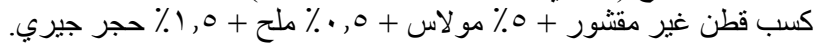

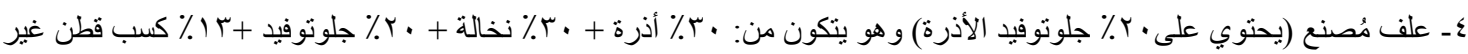

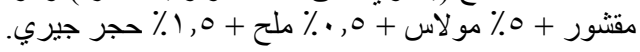
وباستخدام المواد العلفية الخشنة تم تكوين العلائق التجريبية الأربعة كما يلي:-

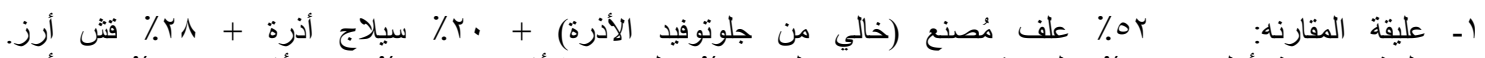

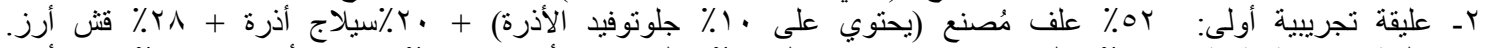

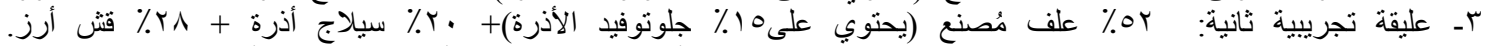

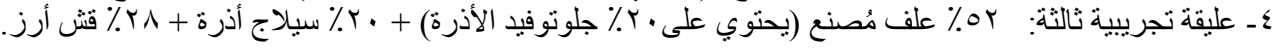

وقد تم تكوين العلائق حتى تكون متماتلة تقريباً فى محتو اها من البروتين الخام والطاقة. تم تغذية حيو انات التجربة فردياً وتم إجر اء تجارب الهضم بطريقة مستخلص الرماد غير الترباد الذائب فى الحامض. وكانت أهم النتائج المنحصل عليها كما يلى:

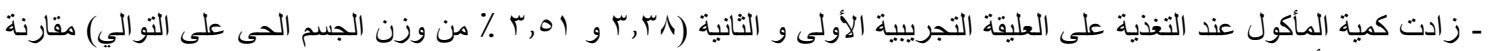

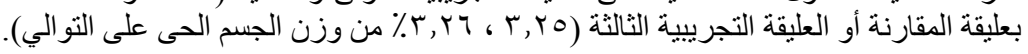

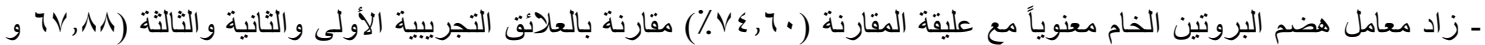

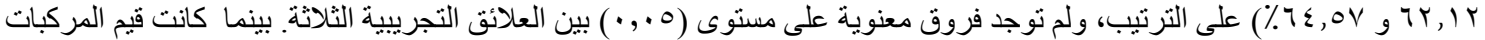

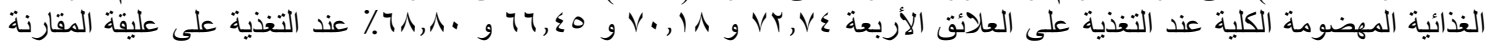
و العلائق التجريبية الأولى و الثانية و الثالثة على التو الثى.

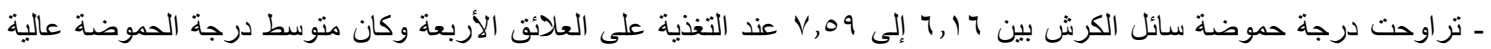

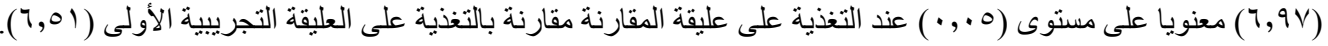

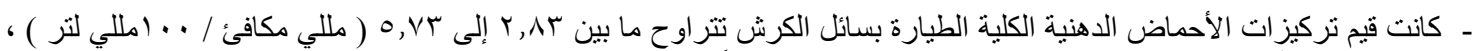

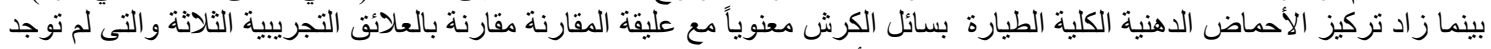

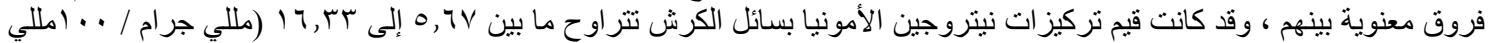
التر) عند التغذية على العلائق الأربعة.

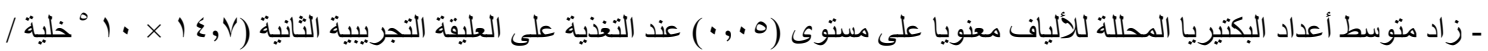

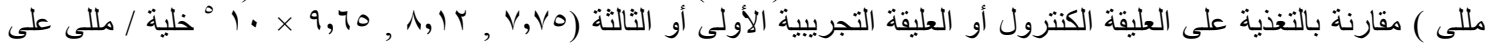




\section{Maklad et al.}

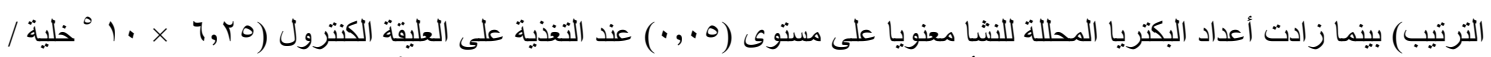

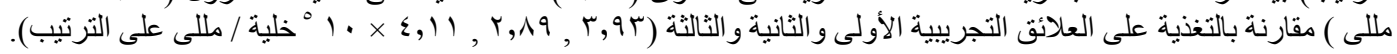

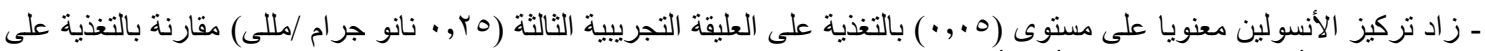

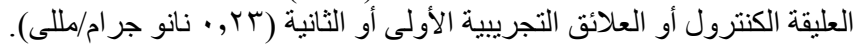

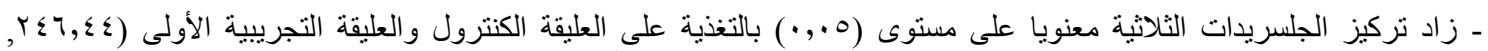

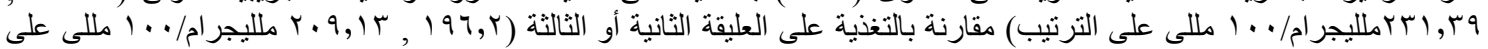

الترنيب).

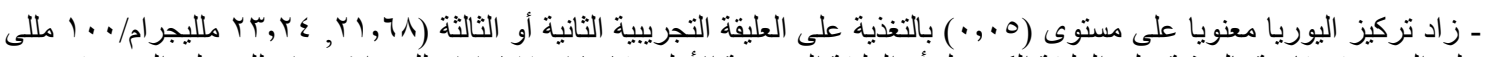

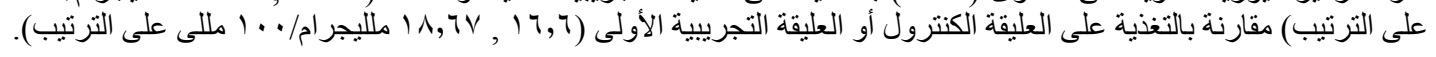

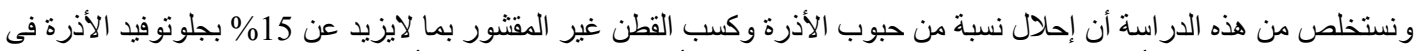

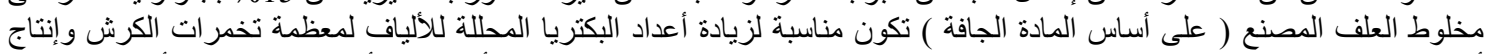
أحماض دهنية طيارة وتكوين بروتين ميكروبي مما يؤدى الى زيادة الإستفادة من الطاقة والأحماض الأبكان الأمينية فى علائق الأبقار الفريزيان 